А. І. Зоренко ${ }^{1}$, бакалавр, Г. А. Вірченко ${ }^{2}$, д.т.н., професор

\title{
БЕЗПІЛОТНИЙ ЛІТАЛЬНИЙ АПАРАТ ІЗ ПРЯМИМ ТА АРОЧНИМ КРИЛОМ
}

En The purpose of this article is to develop a methodology for calculating the aerodynamic computer of the aircraft to straight and arched wings.

Corresponding unmanned aerial vehicle has been considered for the development of methodology. This design is necessary to achieve greater lift force which enables the implementation of a vertical takeoff and landing.

Scientific novelty lies in the combination of design already exist-ing of aircraft with arched wings and multicopter, implement-ing vertical takeoff.

This article describes a method of computer calculation of aerodynamic-cal

\footnotetext{
${ }^{1}$ Національний технічний університет Украӥни "Київський політехнічний інститут", кафедра приладів та систем керування літальними апаратами

${ }^{2}$ Національний технічний університет України "Київський політехнічний інститут", кафедра нарисної геометрії, інженерної та комп'ютерної графіки
} 
characteristics for unmanned aircraft to straight and arched wings. To develop a methodology for the selection of the profile were used, calculation of aerodynamic characteristics for an isolated wing, as well as the construction of the velocity diagrams and overloads for further Designing-of unmanned aircraft to straight and arched wings.

According to the calculation results it can be concluded that the subject of the summer-tive device can perform a vertical take-off and landing on nepod-preparaareas and in urban environments.

Ru Описана методика компьютерного расчета аэродинамических характеристик для беспилотного летательного аппарата с прямым и арочным крылом. Для разработки методики были применены подбор профиля, расчёт аэродинамических характеристик для изолированного крыла, а также построение диаграммы скоростей и перегрузок для дальнейшего проектирования беспилотного летательного аппарата с прямым и арочным крылом.

\section{Вступ}

Нині безпілотні літальні апарати (БПЛА) широко використовуються для вирішення військових та цивільних задач. При експлуатації для БПЛА потрібні підготовлені злітно-посадкові полоси або катапульти, на створення яких витрачається багато часу та коштів. 3 метою подолання цих недоліків застосовуються різноманітні аеродинамічні схеми БПЛА для отримання покращених льотно-технічних характеристик.

Даним дослідженням опрацьовується БПЛА з арочною вставкою під крилом. Особливістю зазначеної конструкції є замкнута арочна вставка під крилом, що при обдуванні гвинтом підвищує підйомну силу й забезпечує можливість здійснення вертикального зльоту та посадки на непідготовленій місцевості.

Були проаналізовані існуючі методи розрахунків аеродинамічних характеристик легких літальних апаратів [1], кільцевих вставок [2, 3], визначення діючих навантажень на конструкцію планера літака та кільцевих вставок [4], вибору силового набору планера літака та кільцевих вставок $[1,5]$, їх оптимізації [6], моделювання цих елементів у $C A D / C A M / C A E$ системах.

Головною проблемою при цьому залишається відсутність методів визначення розподілення навантажень на крило з арочною вставкою, розрахунків силових елементів для прямого крила та арочної вставки, оптимізації конструкції. Для проектування даного літального апарата було вперше запропоновано інтеграцію двох окремих методів розрахунків прямого й арочного крила, а також об'єднання методів визначення навантажень на пряме та арочне крило. 


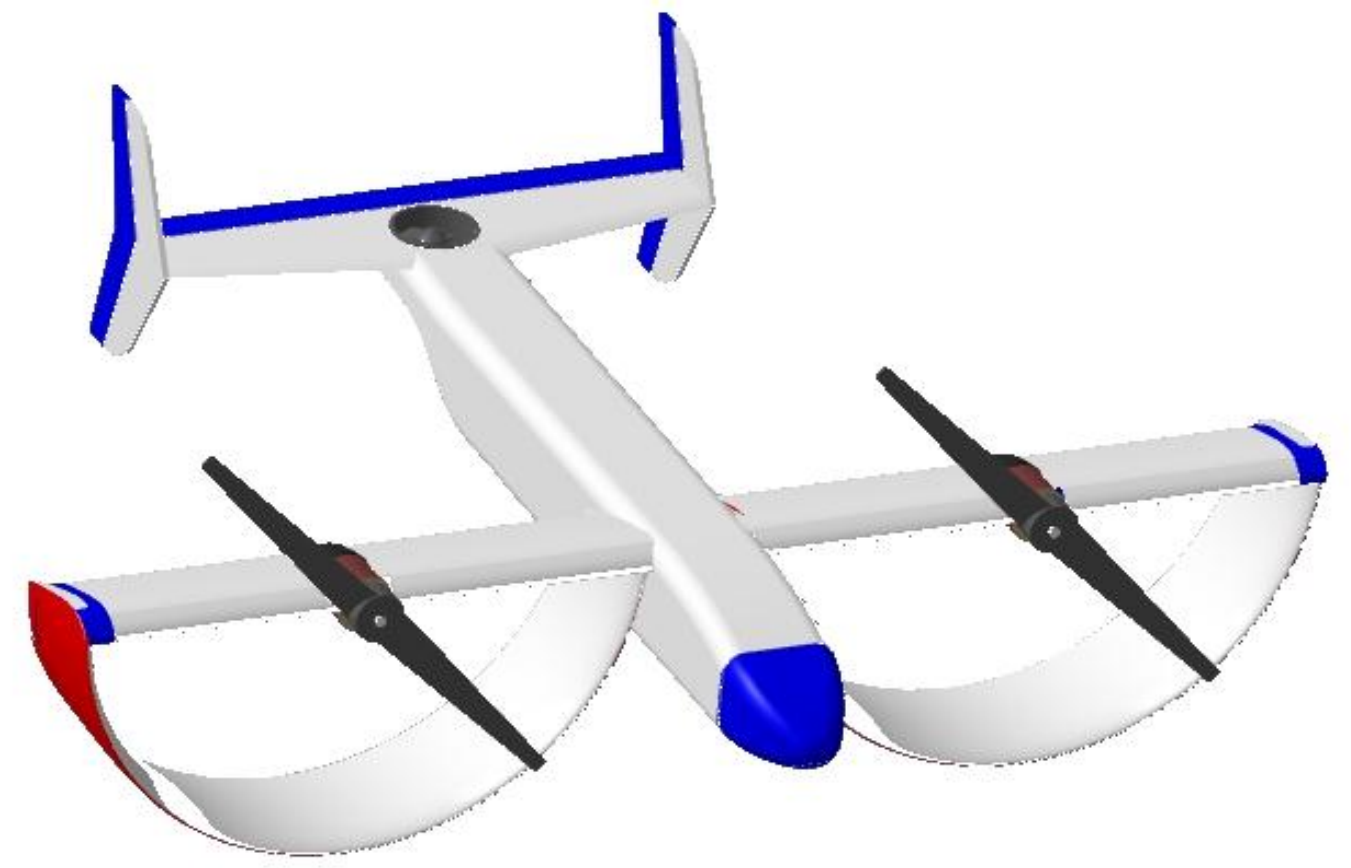

Рис. 1. Загальний вигляд БПЛА з прямим та арочним крилом

\section{Постановка задачі}

Розробити методику комп'ютерних розрахунків аеродинамічних характеристик ізольованого прямого та арочного крила. За допомогою програми Profili2 та авіаційних правил частини 23.

\section{Результати досліджень}

Крило досліджуваного БПЛА розглядається як пряме постійного перерізу. Кільцева вставка також постійного перерізу.

На першому етапі підбирається аеродинамічний профіль для прямого й арочного крила та розраховується число Рейнольдса [1]

$$
R e=\frac{\rho \cdot V_{2} \cdot b}{\eta}=\frac{1,225 \cdot 21,32 \cdot 0,11}{18,37}=0,1563 \cdot 10^{6}
$$

де $\eta-$ динамічна в'язкість, $\eta=18,37$ Па·с; $\rho-$ густина повітря, $\rho=$ $1,225 \mathrm{\kappa г} / \mathrm{M}^{3} ; V_{2}-$ швидкість потоку, $V_{2}=21,32 \mathrm{м} / \mathrm{c} ; b-$ хорда крила, $b=0,11 \mathrm{м}$. Дослідження існуючих аналогів засвідчило, що для створюваного БПЛА потрібен симетричний профіль. 3 цією метою розглянуто профілі NACA серії $230 X X$. Моделювання їх обтікання дало результати, які для наочності подані у вигляді графіків на рис. 2 ... 4. 

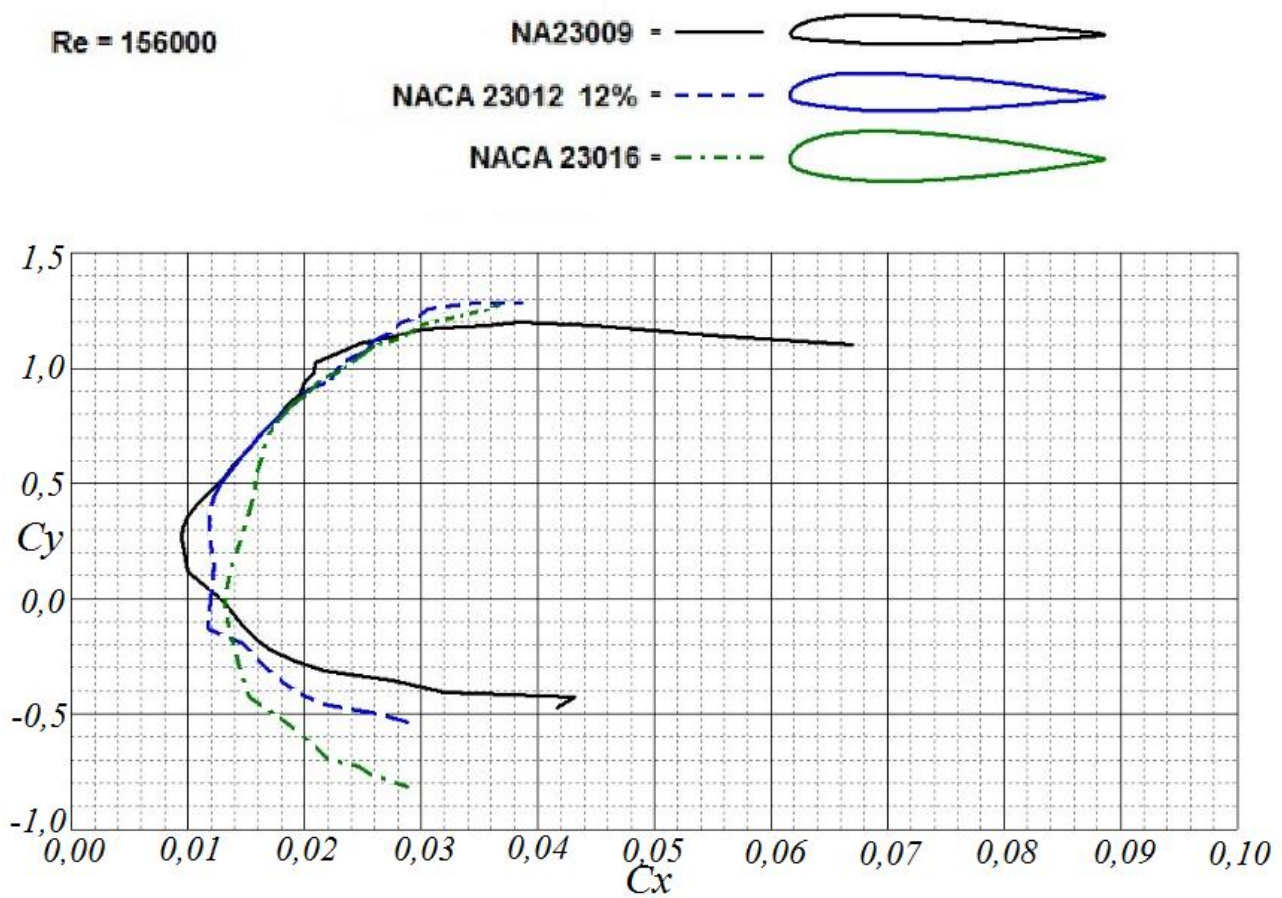

Рис. 2. Графік поляр для трьох профілів.

$C y$ - коефіцієнт підйомної сили; $C x$ - коефіцієнт опору повітря

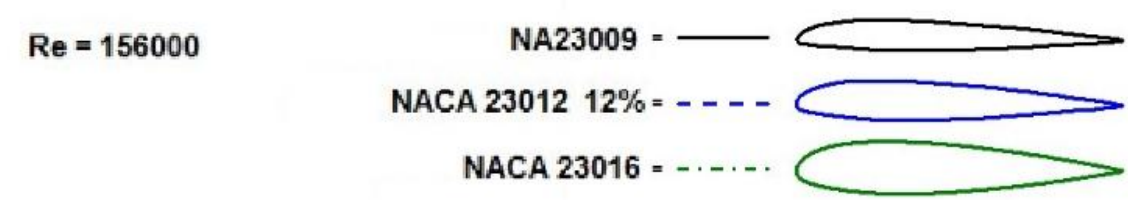

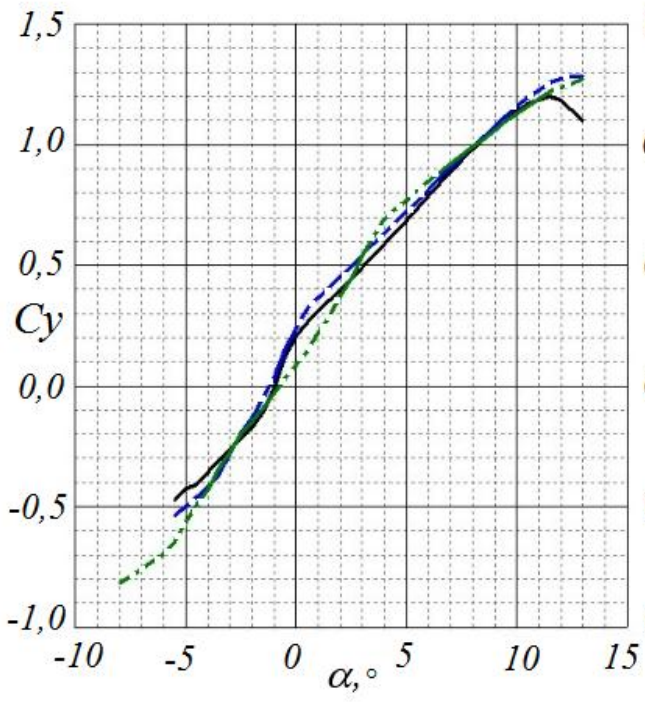

a

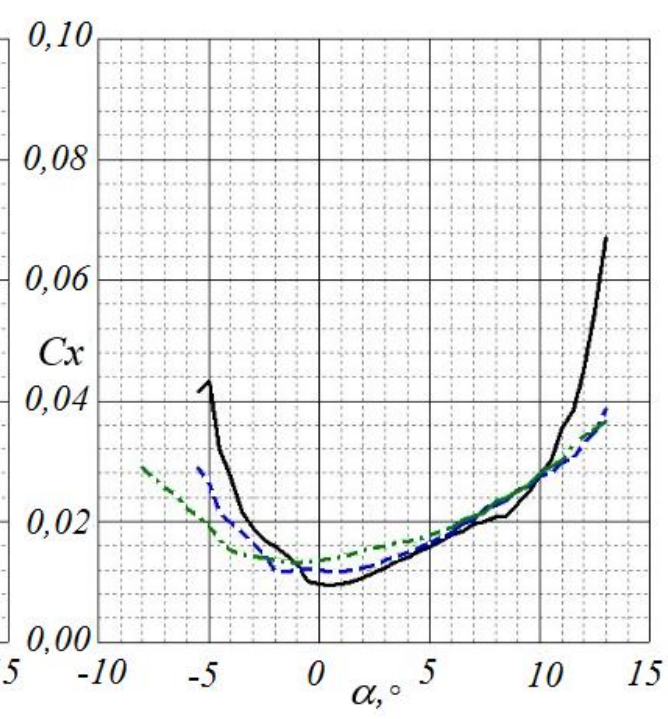

6

Рис. 3. Залежності від кута $\alpha$ атаки профілю:

а - коефіцієнта $C y$ підйомної сили,

б - коефіцієнта $C x$ опору повітря 


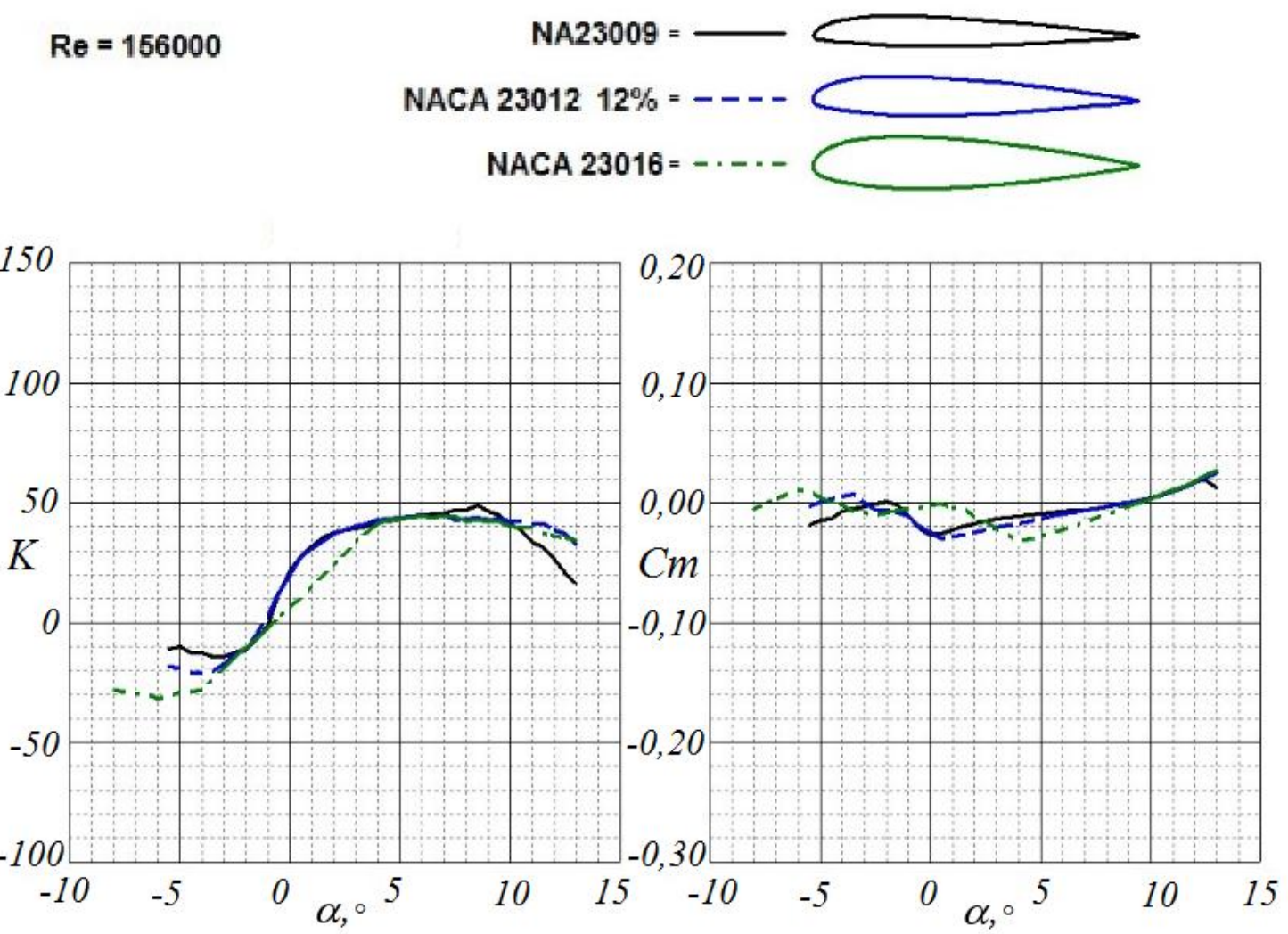

a

Рис. 4. Залежність відкута $\alpha$ атаки профілю:

а - коефіцієнта $K$ аеродинамічної якості,

б - положення $C m$ точки центра тиску

Наведені на графіках дані показують, що найбільш вигідний профіль $N A C A$ серіï 23012, оскільки для визначеного вище числа Re забезпечує максимальну підйомну силу. Для кільцевої вставки профіль NACA серії 23012 теж найбільш доцільний, бо реалізує максимальну аеродинамічну якість для опрацьовуваного числа $R e$.

На другому emani аналізуються графіки поляри (рис. 5) та аеродинамічної якості (рис. 6) для прямого крила з кільцевою вставкою.

Як видно з рис. 6, максимальне значення коефіцієнта $K$ аеродинамічної якості досягається при швидкості V=122 км/год.

На третьому етапі будується графік швидкостей та перевантажень згідно з авіаційними правилами АП-23 [7].

Розраховується крейсерська швидкість [7]

$$
V_{c}^{\text {min }}=33 \cdot \sqrt{\frac{G}{S}}=33 \cdot \sqrt{\frac{0.92}{0,11}}=26,38 \mathrm{~m} / \mathrm{c} .
$$

де $V_{c}^{\text {min }}$-мінімальне значення крейсерської швидкості, м/с; 


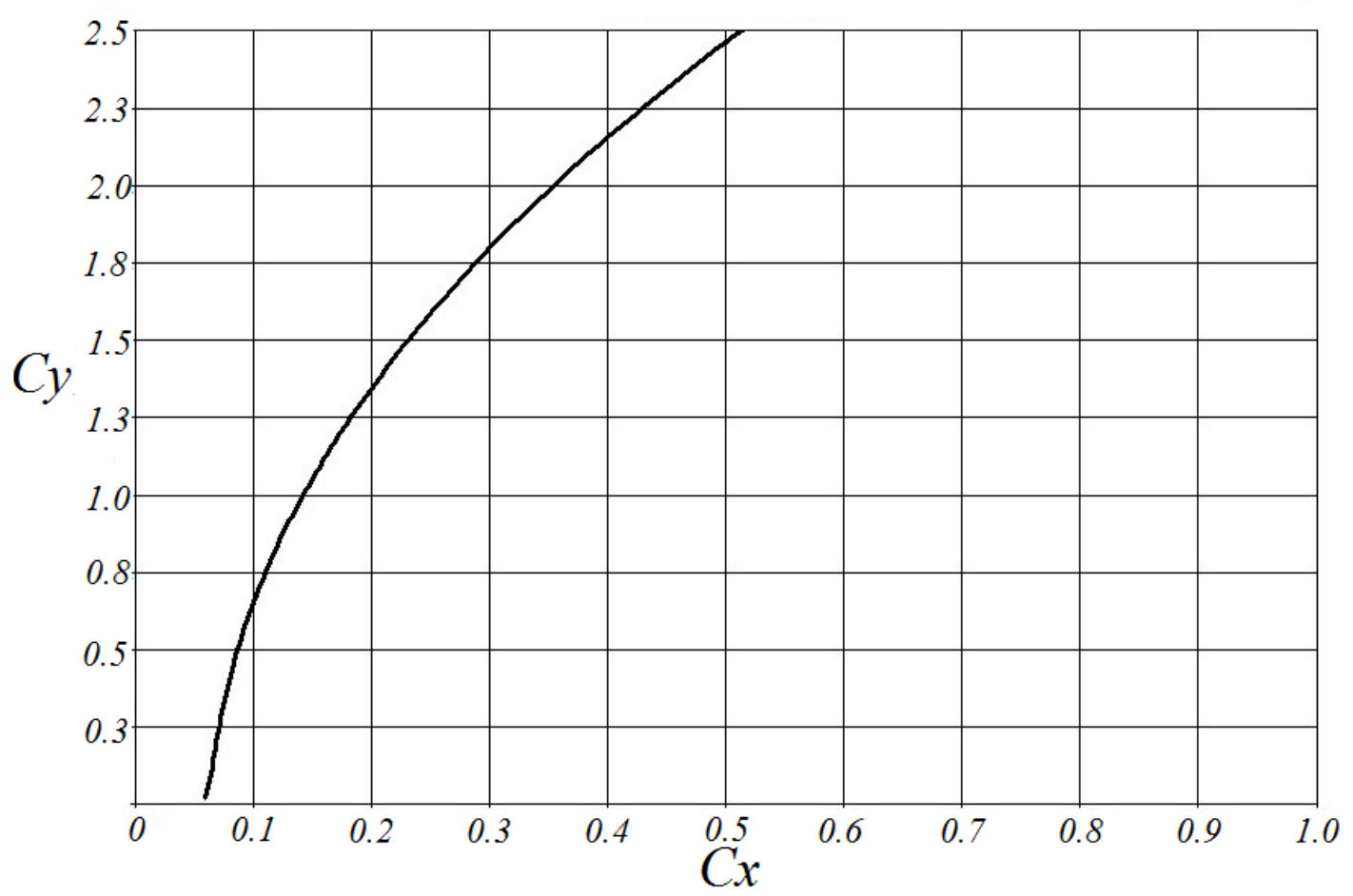

Рис. 5. Поляра ізольованого крила:

$C y$ - коефіцієнт підйомної сили прямого та арочного крила, $C x$ - коефіцієнт опору для прямого та арочного крила

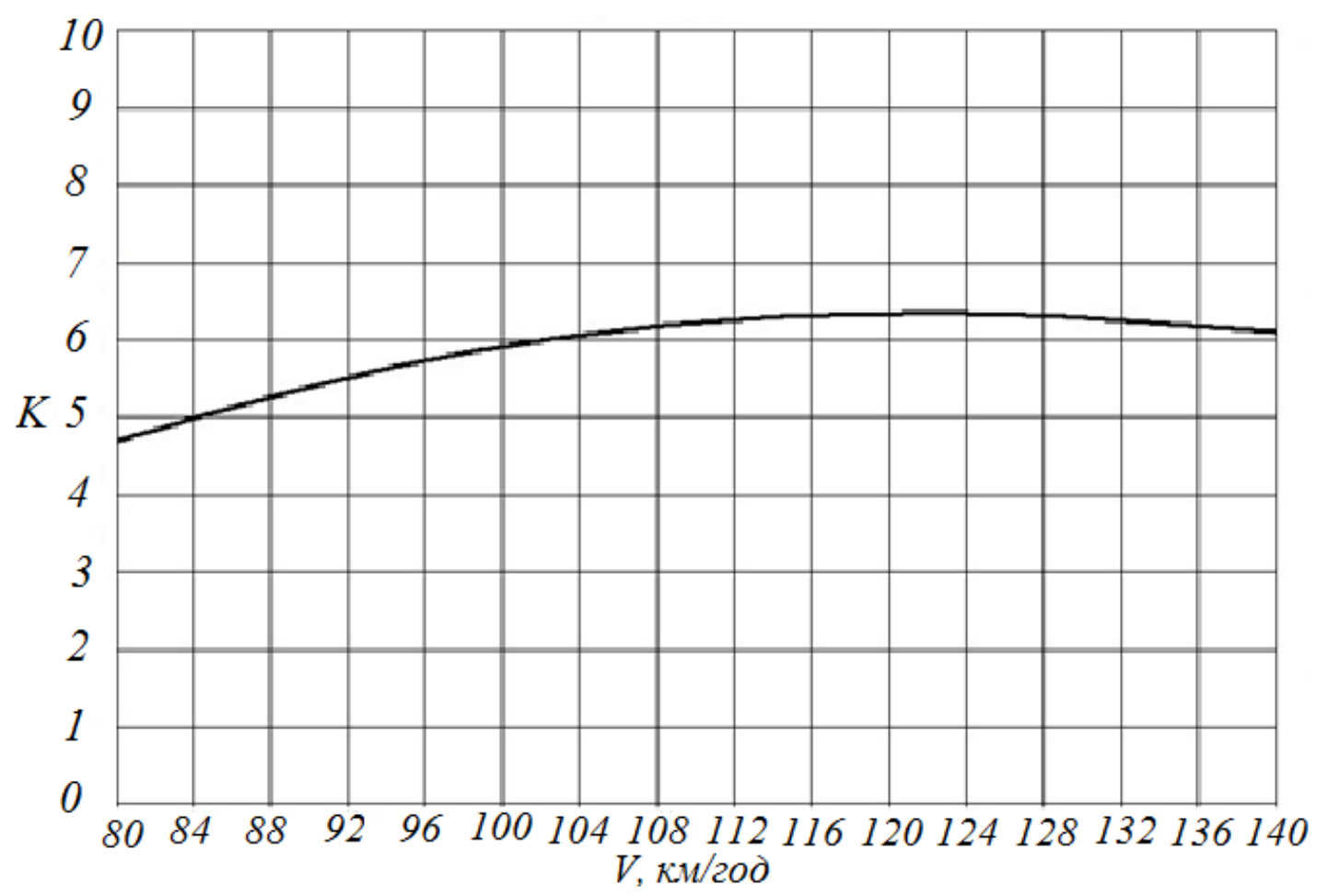

Рис. 6. Залежність аеродинамічної якості БПЛА від швидкості. $K$-якість; $V$ - швидкість 
$\bar{G} / S$ - питоме навантаження на крило при відповідній вазі в розрахункових випадках, кгс/ $\mathrm{M}^{2}$;

$\mathrm{G}$ - максимальна розрахункова вага літака, 0,92 кгс;

$\mathrm{S}$ - площа крила, $\mathrm{S}=0,11 \mathrm{~m}^{2}$.

Обчислюється швидкість звалювання [7]

$$
\begin{aligned}
& \mathrm{V}_{\mathrm{s} \max }=\sqrt{\frac{2 \cdot \mathrm{G}}{\mathrm{C}_{\max 36} \cdot \rho \cdot \mathrm{S}}}=\sqrt{\frac{2 \cdot 0.92}{0,011 \cdot 1,225 \cdot 0.11}}=9,44 \mathrm{M} / \mathrm{c}, \\
& \mathrm{V}_{\mathrm{s} \min }=\sqrt{\frac{2 \cdot \mathrm{G}}{\mathrm{C}_{\min 36} \cdot \rho \cdot \mathrm{S}}}=\sqrt{\frac{2 \cdot 0.92}{0,005 \cdot 1,225 \cdot 0.11}}=13,61 \mathrm{~m} / \mathrm{c}
\end{aligned}
$$

де $V_{s}$ max - максимальне значення швидкості звалювання, м/с;

$V_{s}$ min - мінімальне значення швидкості звалювання, $\mathrm{M} / \mathrm{c}$;

$C y_{\max }$ - максимальне значення коефіцієнта підйомної сили, $C y_{\max }=0,011$;

$C y_{\min }$ - мінімальне значення коефіцієнта підйомної сили, $C y_{\min }=0,005$;

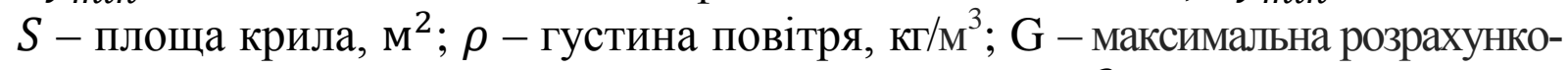
ва вага літака, 0,92 кгс; $\mathrm{S}-$ площа крила, $\mathrm{S}=0,11 \mathrm{M}^{2} . \rho-$ густина повітря, $\rho=1,225 \mathrm{\kappa} \Gamma / \mathrm{M}^{3}$.

Розраховується маневрена швидкість [7]

$$
\begin{gathered}
\mathrm{V}_{\mathrm{a} \text { max }}=\mathrm{V}_{\mathrm{s} \text { max }} \cdot \sqrt{\mathrm{n}^{\mathrm{e}}{ }_{\max }}=9,69 \cdot \sqrt{4,4}=20,27 \mathrm{M} / \mathrm{c}, \\
\mathrm{V}_{\mathrm{a} \text { min }}=\mathrm{V}_{\mathrm{s} \text { min }} \cdot \sqrt{\mathrm{n}^{\mathrm{e}}{ }_{\min }}=13,71 \cdot \sqrt{1,76}=15 \mathrm{M} / \mathrm{c} .
\end{gathered}
$$

де $V_{a \text { max }}$ - максимальне значення маневреної швидкості, м/с;

$V_{a \text { min }}$ - мінімальне значення маневреної швидкості, м/с;

$V_{s} \max -$ максимальне значення швидкості звалювання, $V_{s} \max =9,69 \mathrm{M} / \mathrm{c}$;

$V_{s \min }$ - мінімальне значення швидкості звалювання, $V_{s \min }=13,71 \mathrm{M} / \mathrm{c}$; $n_{\text {max }}^{e}$ - максимальне значення перевантаження, $n_{\text {max }}^{e}=4,4 ; n_{\text {min }}^{\mathrm{e}}$ - мінімальне значення перевантаження, $n_{\text {min }}^{\mathrm{e}}=1,76$.

Визначається швидкість пікірування [7]

$$
V_{d}=1,5 \cdot V_{c}=1,5 \cdot 26,5=34,72 \mathrm{M} / \mathrm{c}
$$

де $V_{d}$ - швидкість пікірування, м/с;

$V_{\text {c }}$ - крейсерська швидкість, $V_{c}=26,4$ м/с.

За АП-23 існують обмеження для випадку польоту в неспокійному повітрі.

Урахування поривів при крейсерській швидкості обчислюється [7]

$$
\mathrm{n}_{+}=1+\frac{\mathrm{K}_{\mathrm{g}} \cdot U_{d e} \cdot C_{y}^{\alpha} \cdot \mathrm{v}_{\mathrm{c}}}{16 \cdot(\mathrm{G} / \mathrm{s})}=1+\frac{0,131 \cdot 15,2 \cdot 6,07 \cdot 26,55}{16 \cdot(0,92 / 0,11)}=3,4 ;
$$




$$
\mathrm{n}_{-}=1-\frac{K_{g} \cdot U_{d e} \cdot C_{y}^{\alpha} \cdot \mathrm{v}_{\mathrm{c}}}{16 \cdot(\mathrm{G} / \mathrm{s})}=1-\frac{0,131 \cdot 15,2 \cdot 6,07 \cdot 26,55}{16 \cdot(0,92 / 0,11)}=-1,4 \text {, }
$$

де $\mathrm{n}$ - значення перевантаження;

$K_{g}$ - коефіцієнт послаблення пориву, $K_{g}=0,131$;

$U_{d e}-$ ефективна індикаторна швидкість, $U_{d e}=15,2 \mathrm{M} / \mathrm{c}$;

$C_{y}^{\alpha}$ - похідна коефіцієнта нормальної підіймальної сили літака, $C_{y}^{\alpha}=6,07$

$V_{\text {c }}$ - крейсерська швидкість, $V_{c}=26,55 \mathrm{~m} / \mathrm{c}$;

$G / S$ - питоме навантаження на крило при відповідній вазі в розрахункових випадках, кгс/ $\mathrm{M}^{2}$;

$G$ - максимальна розрахункова вага літака, 0,92 кгс;

$S$ - площа крила, $\mathrm{S}=0,11 \mathrm{M}^{2}$.

Урахування поривів при пікіруючій швидкості

$$
\begin{gathered}
\mathrm{n}_{+}=1+\frac{\mathrm{K}_{\mathrm{g}} \cdot U_{d e} \cdot C_{y}^{\alpha} \cdot \mathrm{v}_{\mathrm{d}}}{16 \cdot(\mathrm{G} / \mathrm{s})}=1+\frac{0,131 \cdot 7,6 \cdot 5,34 \cdot 37,72}{16 \cdot(0,92 / 0,11)}=2,5 \\
\mathrm{n}_{-}=1-\frac{\mathrm{K}_{\mathrm{g}} \cdot U_{d e} \cdot C_{y}^{\alpha} \cdot \mathrm{v}_{\mathrm{d}}}{16 \cdot(\mathrm{G} / \mathrm{s})}=1-\frac{0,131 \cdot 7,6 \cdot 5,34 \cdot 37,72}{16 \cdot(0,92 / 0,11)}=-0,5
\end{gathered}
$$

де $\mathrm{n}$ - значення перевантаження;

$K_{g}$ - коефіцієнт послаблення пориву, $K_{g}=0,131$;

$U_{d e}-$ ефективна індикаторна швидкість, $U_{d e}=7,6 \mathrm{M} / \mathrm{c}$;

$C_{y}^{\alpha}$ - похідна коефіцієнта нормальної підіймальної сили літака,

$C_{y}^{\alpha}=5,34$;

$V_{\text {c }}$ - крейсерська швидкість, м/с;

$V_{d}$ - швидкість пікірування, $V_{d}=37,72 \mathrm{~m} / \mathrm{c}$;

$G / S$ - питоме навантаження на крило при відповідній вазі в розрахункових випадках, кгс/ $\mathrm{M}^{2}$;

$G$ - максимальна розрахункова вага літака, 0,92 ктс; $S$ - площа крила, $S=0,11 \mathrm{M}^{2}$.

На основі отриманих на третьому етапі результатів побудовано графік швидкостей та перевантажень, який зображено на рис. 7. 
Механіка елемен

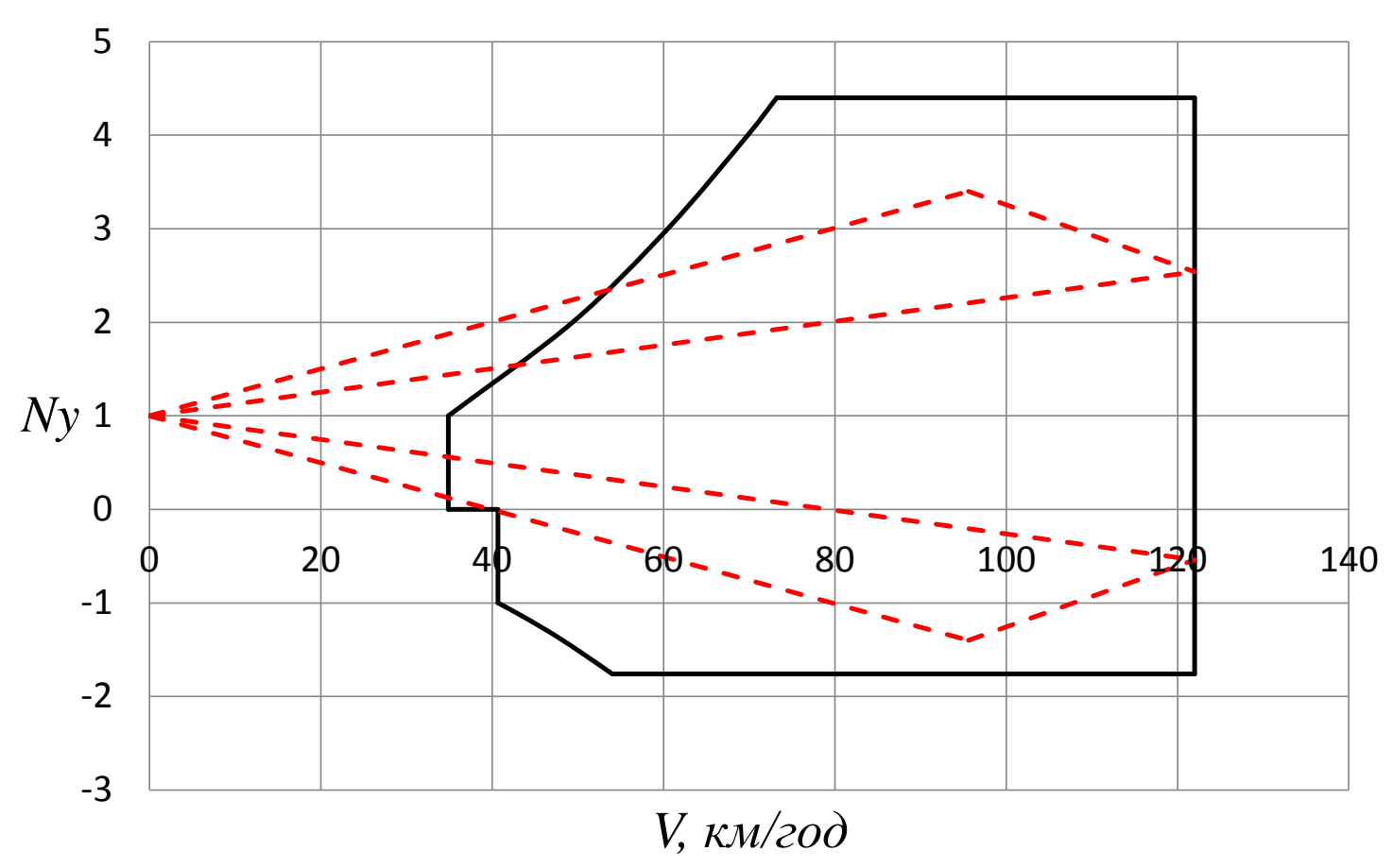

Рис. 7. Діаграма швидкостей та перевантажень

Було розраховано число Рейнольдса, розглянуто 3 профілі марки $N A C A$ серії $230 X X$, виконано моделювання їх обтікання та по отриманим графікам обрано профіль для прямої та арочної частини крила. Це дає можливість побудувати крило та провести його аеродинамічний розрахунок. Побудовано графіки поляри ізольованого крила і графік аеродинамічної якості на яких показано аеродинамічні характеристики літального апарата. Згідно з даними результатами можливо розрахувати навантаження, які діють на крило літального апарата. Розраховано та побудовано діаграму швидкостей і перевантажень, з якої видно, що найбільші навантаження будуть діяти при максимальній маневреній швидкості.

\section{Висновки}

Запропоновано методику визначення аеродинамічних характеристик БПЛА з прямим та арочним крилом, яка представлена у вигляді послідовних етапів розрахунків. Отримані наукові результати дають змогу надалі проводити розрахунки конструкції планера для удосконалення вже існуючих літальних апаратів 3 подібною схемою крила та здійснювати комп’ютерне моделювання її елементів для розрахунків на міцність.

\section{Список використаної літератури}

1. Бадягин А. А. Проектирование легких самолетов / А. А. Бадягин, Ф. А. Мухаедов., 1978. - 208 с.

2. Глаголев А. Н. Конструкция самолетов / А. Н. Глаголэв., 1975. - 408 с. 
3. Кан С. Н. Расчет самолетов на прочность / С. Н. Кан, И. А. Свердлов., 1966. -264 c.

4. Ветчинкин В. П. Конструкция и расчет самолетов на прочность / В. П. Ветчинкин., 2013. - 574 с.

5. Бенуа Ю. Ю. Суда на воздушной подушке / Ю. Ю. Бенуа, В. М. Корсаров., 1962. - 415 с.

6. Николаев Н. И. Летающий вездеход / Н. И. Николаев., 1963. - 104 с.

7. Авиационные правила [Електронний ресурс] // Москва. - 2000. - Режим доступа к ресурсу: http://aviadocs.net/docs. 